\title{
Drivers of disease emergence and spread: Is wildlife to blame?
}

\begin{abstract}
Author:
Richard Kock ${ }^{1}$

Affiliation:

${ }^{1}$ Department of Pathology and Pathogen Biology, Royal Veterinary College, United Kingdom
\end{abstract}

Correspondence to

Richard Kock

Email:

rkock@rvc.ac.uk

\section{Postal address:}

Royal Veterinary College, Hawkshead Lane, North Mymms, Hatfield, Hertfordshire, AL9 7TA, United Kingdom

How to cite this article: Kock, R., 2014, 'Drivers of disease emergence and spread: Is wildlife to blame?', Onderstepoort Journal of Veterinary Research 81(2), Art. \#739, 4 pages. http:// dx.doi.org/10.4102/ojvr. v81i2.739

\section{Note:}

Proceedings of the $2 \mathrm{nd}$ One Health Conference in Africa. Jointly organised by the Southern African Centre for Infectious Disease Surveillance and the Tanzania National Institute for Medical Research, held at the Snow Crest Hotel in Arusha, Tanzania from 16th to 19th April 2013: http://www. sacids.org/kms/frontend/ index.php?m=119.

\section{Copyright:}

(C) 2014. The Authors.

Licensee: AOSIS

OpenJournals. This work

is licensed under the Creative Commons

Attribution License.
The global focus on wildlife as a major contributor to emerging pathogens and infectious diseases (EIDs) in humans and domestic animals is not based on field, experimental or dedicated research, but mostly on limited surveys of literature, opinion and the assumption that biodiversity harbours pathogens. The perceived and direct impacts of wildlife, from being a reservoir of certain human and livestock pathogens and as a risk to health, are frequently overstated when compared to the Global burden of disease statistics available from WHO, OIE and FAO. However organisms that evolve in wildlife species can and do spill-over into human landscapes and humans and domestic animal population and, where these organisms adapt to surviving and spreading amongst livestock and humans, these emerging infections can have significant consequences. Drivers for the spill-over of pathogens or evolution of organisms from wildlife reservoirs to become pathogens of humans and domestic animals are varied but almost without exception poorly researched. The changing demographics, spatial distribution and movements, associated landscape modifications (especially agricultural) and behavioural changes involving human and domestic animal populations are probably the core drivers of the apparent increasing trend in emergence of new pathogens and infectious diseases over recent decades.

\section{Introduction}

The global focus on wildlife as a major contributor to emerging pathogens and infectious diseases (EIDs) in humans and domestic animals is not based on field, experimental or dedicated research, but mostly on surveys of literature that report new diseases corrected for reporting bias (e.g. Jones et al. 2008; Jones et al. 2013). In addition to hotspot mapping, such publications link diseases to possible pathogen origins from various non-domestic animal species. The assessment of these reported trends in EIDs and their impacts is significantly biased by research regarding human immunodeficiency virus (HIV) and AIDS, severe acute respiratory syndrome (SARS) and highly pathogenic avian influenza (HPAI), all of which have an indirect wildlife link. Except for AIDS, the aforementioned diseases have taken a relatively small toll on human life but have incurred huge costs, mostly related to fear induced by perceived pandemic threats and high case fatality rates and resulting from the syndrome's importance being amplified by global media. Political pressure has resulted in strong government responses and international investment in pathogen research and addressing the spread of these agents. However, it is surprising that little has been done so far to deal with the main drivers and amplifiers of the diseases, for example, through a shift in animal production systems or closure of key epidemiological nodes such as live or wet markets (Fournié et al. 2013). The potential for similar events remains or is even more likely than before, given the ever-expanding markets and associated domestic animal production systems, which are conducive to the evolution and amplification of new pathogens. This is further enhanced by the increasing movement and contact between humans, domestic animals and wildlife (Wallace \& Kock 2012).

\section{Disease emergence factors and wildlife}

Reported causes for and drivers of the apparent trends in disease emergence lack, in most cases, strong evidence-based research (Jones et al. 2013). However, there is circumstantial evidence to suggest that novel epidemics and disease syndromes are the result of changing agroecology and human behaviour and movements, intensifying interfaces with certain wildlife species and climate change (Roche \& Guégan 2011).

The inclusion of wildlife in the epidemiology and evolution of EIDs is justified (Keesing et al. 2010), but the role of wildlife is often misrepresented. The idea that biodiversity is the origin of many infectious agents is stating the obvious: where else would new infectious agents come from? It is not that the 'pathways' for emergence are in any way unnatural; rather, it is the opportunities for emergence that are changing and probably on the increase. The most dramatic 
example of this is the emergence of AIDS from the spillover of simian immunodeficiency virus from sooty mangabey and chimpanzees into humans and the subsequent genetic changes (through mutation, recombination or reassortment) enabling the evolution of human pathogens HIV-1 and HIV-2 (Gao et al. 1999). Bush meat, the fragmentation of forest and the development of road systems facilitated the virus's spread to urban centres and eventually to the global human population, causing the most significant epidemic disease in modern times.

Wildlife species are a reservoir of some emerging pathogens, but zoonotic transmission is uncommon and often involves a domestic animal bridge (shown in brackets), for example Crimean-Congo haemorrhagic fever (livestock [Sang 2011]), Japanese encephalitis (pigs [Impoinvil et al. 2011]), nipah virus infection (pigs), hendra virus infection (horses [Field 2010]), plague, trypanosomosis (livestock [Funk et al. 2013]). Some of these examples of emerging zoonoses are a direct result of human interference, for example, the establishment of the pig industry and fruit farms in areas with highdensity bat populations in the case of nipah virus (Pulliam et al. 2012). An additional driver of zoonotic emergence from wildlife is, the creation of wildlife habitats in high-density human settlements or recreational areas for example lyme disease (Levi et al. 2012) in the United States of America and the slaughter and consumption of primates and other bush meat in African causes the spillover of ebola virus to humans (Leroy, Gonzalez \& Baize 2011). It is suggested that such bridges have, over time, resulted in the establishment of a range of human diseases, for example diphtheria, measles, campylobacteriosis small pox, pertussis and mumps (Wolfe, Dunavan \& Diamond 2007). The advent of modern livestock systems is also associated with diseases such as leptospirosis, cysticercosis and echinococcosis and an array of zoonotic infections by pathogens such as the Japanese encephalitis virus, highly pathogenic avian influenza viruses, norovirus, hepatitis E virus, Campylobacter spp., Escherichia coli O157:H7 (toxin code) and the epidemic strain of Salmonella enterica serotype Typhimurium Definitive Type 104 (Altekruse, Cohen \& Swerdlow 1997; Jones et al. 2013).
Figure 1 provides an estimate of global wildlife-related mortalities in humans as a proportion of total incidences in an average year. A log scale was used as the wildlife contribution would otherwise not appear in most cases, which is an indication of how rare they are.

Many wildlife species, from a wide range of taxa, act as temporary or intermediate disease hosts. They can transmit and amplify infections over space and time but are not longterm reservoirs (Table 1). Occasionally, wildlife species are victims of or spillover hosts from domestic animals and even humans (Table 2).

It is interesting that some infections are well tolerated by wild reservoir hosts, as illustrated by the association between wild birds and avian influenza viruses (Alexander

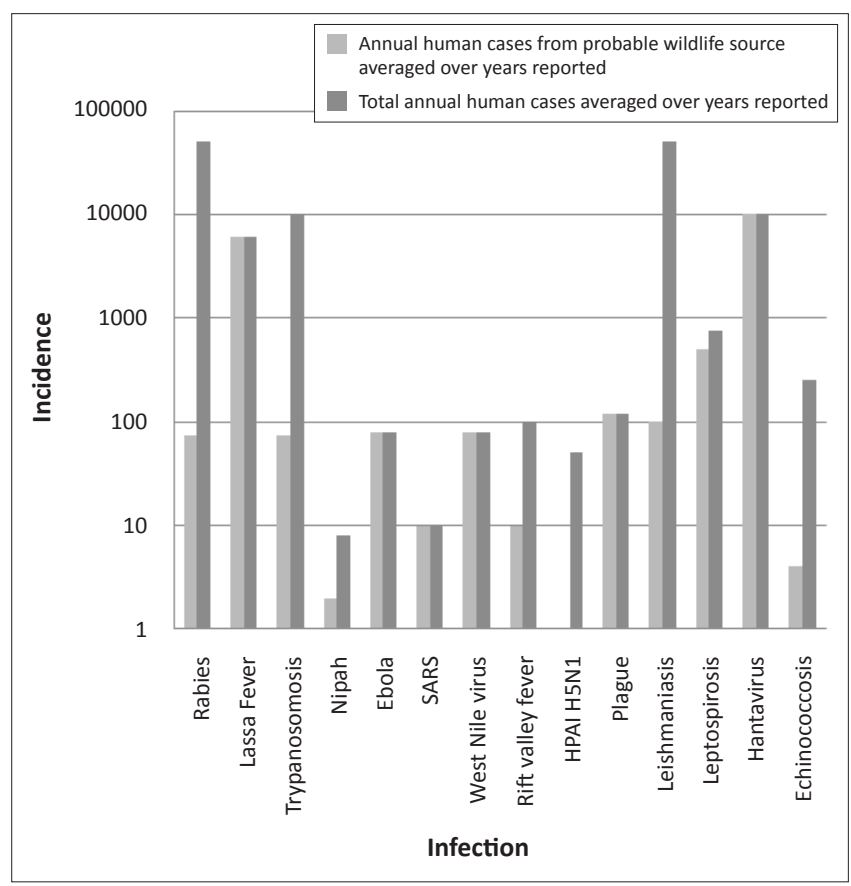

Note: Data estimated from statistics available from the World Health Organization (WHO) Food and Agriculture Organization (FAO) and the World Organisation for Animal Health (OIE). HPAI, highly pathogenic avian influenza; SARS, severe acute respiratory syndrome.

FIGURE 1: Global mortality estimates of infections from a wildlife source in humans as a proportion of total incidence.

TABLE 1: Examples of wildlife taxa that are important hosts, carriers or vectors of human or domestic animal pathogens but not the maintenance hosts.

\begin{tabular}{lll}
\hline Taxon group or animal & Pathogen & Reference \\
\hline African buffalo and artiodactyls & Rift Valley fever virus & Britch et al. (2013) \\
Greater kudu & Rabies virus & Bengis, Kock and Fischer (2002) \\
Anseriformes (wild ducks, geese and swans) & HPAl (H5N1, H5N2) & Feare and Yasué (2006); Gaidet et al. (2012) \\
Great apes, primates and duiker & Ebola viruses & Bermejo et al. (2006); Sharp and Hahn (2011) \\
Mosquitoes, biting flies, sandflies and ticks & Numerous viruses, piroplasms and bacteria & Mackenzie and Jeggo (2013) \\
Gastropods & Intermediate stages of parasitic schistosomes & Johnson et al. (2009) \\
\hline
\end{tabular}

HPAl, highly pathogenic avian influenza

TABLE 2: Examples of wildlife taxa that are impacted by spillover infection from domestic animal or human reservoirs of disease.

\begin{tabular}{|c|c|c|}
\hline Taxon group or animal & Pathogen & Reference \\
\hline African buffalo, artiodactyls, carnivores, pinnipeds & $\begin{array}{l}\text { Morbilliviruses (rinderpest, pestes des petits ruminants, } \\
\text { distemper) }\end{array}$ & Cleaveland et al. (2007); Kock (2006); Härkönen et al. (2006) \\
\hline Great apes & Cold and influenza viruses & Woodford, Butynski and Karesh 2002 \\
\hline Ungulates, primates and carnivores & Mycobacterium tuberculosis complex (human and bovine) & $\begin{array}{l}\text { Keet et al. (2008); Nath and Chakraborty (2012); Obanda } \\
\text { et al. (2013) }\end{array}$ \\
\hline
\end{tabular}




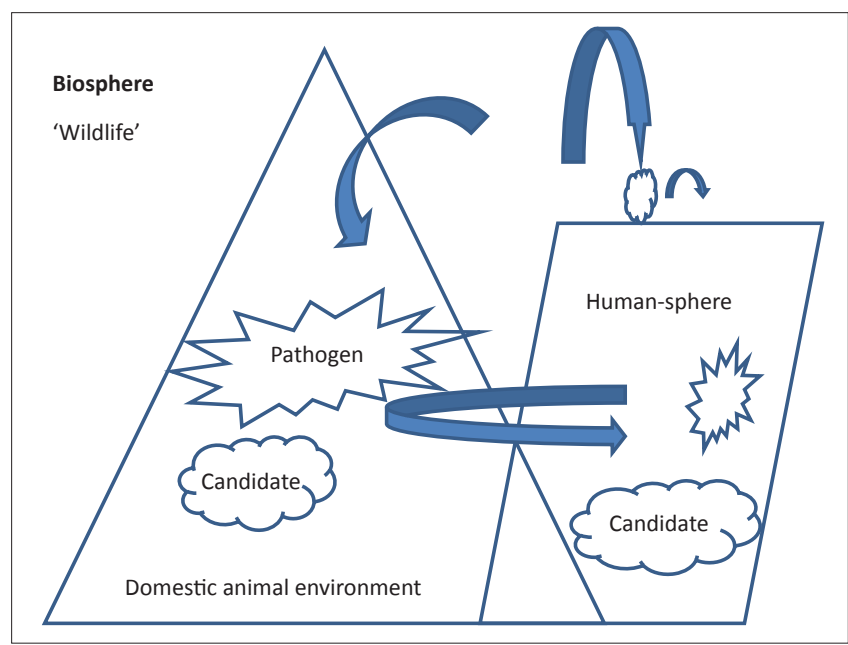

Note: There are an infinite number of candidate pathogens in the biosphere, which provide the raw material for evolution into human and domestic animal pathogens, frequently transmitting across the species barrier.

FIGURE 2: Model of pathogen evolution from the biosphere through contact between wildlife and domestic animals or humans.

2000) and bats and lyssa viruses (Calisher et al. 2006), and the role of communities with respect to infective agents and hosts, transmission and their pathogenicity has recently become a prominent research topic (Johnson \& Thieltges 2010; Randolph \& Dobson 2012). However, when the contact between wild species and domestic animals or humans is intensified, spillover occurs with direct pathogenic impact or opportunity for evolution of these viruses in new hosts, as evidenced by the emergence of HPAI and SARS (Tang et al. 2009). Figure 2 provides a simplified model of this process.

\section{Conclusion}

In conclusion, evidence suggests that we should not see wildlife as a direct source of pathogen threats, but rather as an indirect source of candidate pathogens. A smarter solution than trying to identify cryptic potential infection from wildlife would be to address human behaviour and actions, which are driving most of the emerging disease syndromes. If science provides the evidence and critical control points, and health sectors and society engage within the developing human landscape, pathogen emergence need not be catastrophic in its impact, and humans and domestic animals can continue to co-exist with wildlife in a rich, resilient natural world.

\section{Acknowledgements Competing interests}

The author declares that he has no financial or personal relationship(s) that may have inappropriately influenced him in writing this article.

\section{References}

Alexander, D.J., 2000, 'A review of avian influenza in different bird species', Veterinary Microbiology 74, 3-13.

Altekruse, S.F., Cohen, M.L. \& Swerdlow, D.L., 1997, 'Emerging foodborne diseases', Emerging Infectious Diseases 3(3), 285-293. http://dx.doi.org/10.3201/ eid0303.970304

Bengis, R.G., Kock, R.A. \& Fischer, J., 2002, 'Infectious animal diseases: The wildlife/ livestock interface', Review Scientifique Technique Office Internationale des Epizooties 21(1), 53-65.
Bermejo, M., Rodríguez-Teijeiro, J.D., Illera, G., Barroso, A., Vilà, C. \& Walsh, P.D., 2006, 'Ebola outbreak killed 5000 gorillas', Science 314(5805), 1564. http://dx.doi. org/10.1126/science.1133105

Britch, S.C., Binepal Y.S., Ruder, M.G., Kariithi, H.M., Linthicum, K.J., Anyamba, A. et al., 2013, 'Rift Valley fever risk map model and seroprevalence in selected wild ungulates and camels from Kenya', PLOS ONE 8(6): e66626. http://dx.doi. org/10.1371/journal.pone.0066626

Calisher, C.H., Childs, J.E., Field, H.E., Holmes, K.V. \& Schountz, T., 2006, 'Bats: Important reservoir hosts of emerging viruses', Clinical Microbiology Reviews Important reservoir hosts of emerging viruses', Clinical
19(3), 531-545. http://dx.doi.org/10.1128/CMR.00017-06

Cleaveland, S., Mlengeya, T., Kaare, M., Haydon, D., Lembo, T., Laurenson, M.K. et al., 2007, 'The conservation relevance of epidemiological research into carnivore viral diseases in the Serengeti', Conservation Biology 21(3), 612-622. http://dx.doi. diseases in the Serengeti', Conservation
$\mathrm{org} / 10.1111 / \mathrm{j} .1523-1739.2007 .00701 . x$

Feare, C.J. \& Yasué, M., 2006, 'Asymptomatic infection with highly pathogenic avian influenza H5N1 in wild birds: How sound is the evidence?', Virology Journal 3:96. http://dx.doi.org/10.1186/1743-422X-3-96

Field, H., 2010, 'Hendra virus outbreak with novel clinical features, Australia', Emerging Infectious Diseases 16(2), 2008-2010. http://dx.doi.org/10.3201/eid1602.090780

Fournié, G., Guitian, J., Desvaux, S., Cuong, V.C., Dung, D.H., Pfeiffer, D.U. et al., 2013, 'Interventions for avian influenza A (H5N1) risk management in live bird market networks', Proceedings of the National Academy of Sciences 110(22), 9177-9182. http://dx.doi.org/10.1073/pnas.1220815110

Funk, S., Nishiura, H., Heesterbeek, H., Edmunds, W.J. \& Checchi, F., 2013, 'Identifying transmission cycles at the human-animal interface: The role of animal reservoirs in maintaining gambiense human African trypanosomiasis', PLOS Computational in maintaining gambiense human African trypanosomiasis', PLoS Computali.
Biology 9(1), e1002855. http://dx.doi.org/10.1371/journal.pcbi.1002855

Gaidet, N., Cattoli, G., Hammoumi, S., Newman, S.H., Hagemeijer, W., Takekawa, J.Y et al., 2008, 'Evidence of infection by H5N2 highly pathogenic avian influenza et al., 2008, 'Evidence of infection by H5N2 highly pathogenic avian influenza
viruses in healthy wild waterfowl', PLoS Pathogens 4(8), e1000127. http://dx.doi. viruses in healthy wild waterfowl',
org $10.1371 /$ journal.ppat.1000127

Gao, F., Bailes, E., Robertson, D. L., Chen, Y., Rodenburg, C. M., Michael, S. F., Cumminsk L.B., Arthur L.O. , Peeters M, Shaw, G. M., Sharp, P. M. \& Hahn, B.H.,1999, 'Origin of HIV-1 in the chimpanzee Pan troglodytes troglodytes', Nature (Letters) 397, of HIV-1 in the chimpanzee Pan troglodyt
$436-441$. http://dx.doi.org/10.1038/17130

Härkönen, T., Dietz, R., Reijnders, P., Teilmann, J., Harding, K., Hall, A. et al., 2006, 'The 1988 and 2002 phocine distemper virus epidemics in European harbour seals', 1988 and 2002 phocine distemper virus ep
Diseases of Aquatic Organisms 68, 115-130.

Impoinvil, D.E., Solomon, T., Schluter, W.W., Rayamajhi, A., Bichha, R.P., Shakya, G. et al., 2011, 'The spatial heterogeneity between Japanese encephalitis incidence distribution and environmental variables in Nepal', PLOS ONE 6(7), e22192. http:// distribution and environmental variables in
dx.doi.org/10.1371/journal.pone.0022192

Johnson, P.T.J. \& Thieltges, D.W., 2010, 'Diversity, decoys and the dilution effect: How ecological communities affect disease risk', Journal of Experimental Biology 213(6), 961-970. http://dx.doi.org/10.1242/jeb.037721

Johnson, P.T.J., Lund, P.J., Hartson, R.B. \& Yoshino, T.P., 2009, 'Community diversity reduces Schistosoma mansoni transmission, host pathology and human infection
risk', Proceedings of the Royal Society B 276(1662), 1657-1663. http://dx.doi. risk', Proceedings of the Roy
$\mathrm{org} / 10.1098 / \mathrm{rspb} .2008 .1718$

Jones, K.E., Patel, N.G., Levy, M.A., Storeygard, A., Balk, D., Gittleman, J.L. et al., 2008 'Global trends in emerging infectious diseases', Nature 451(7181), 990-993. http://dx.doi.org/10.1038/nature06536

Jones, B.A., Grace, D., Kock, R., Alonso, S., Rushton, J. \& Said, M.Y., 2013, 'Zoonosis emergence linked to agricultural intensification and environmental change',
Proceedings of the National Academy of Sciences 110(21), 8399-8404. http:// Proceedings of the National Academy
dx.doi.org/10.1073/pnas.1208059110

Keesing, F., Belden, L.K., Daszak, P., Dobson, A., Harvell, C.D., Holt, R.D. et al., 2010 Impacts of biodiversity on the emergence and transmission of infectious diseases', Nature 468(7324), 647-652. http://dx.doi.org/10.1038/nature09575

Keet, D.F., Michel, A.L., Bengis, R.G., Becker, P., Van Dyk, D.S., Van Vuuren, M. et al., 2008, 'Intradermal tuberculin testing of wild African lions (Panthera leo) naturally exposed to infection with Mycobacterium bovis', Veterinary Microbiology 144(34), 384-391. http://dx.doi.org/10.1016/j.vetmic.2010.01.028

Kock, R.A., 2006, 'Rinderpest and wildlife', in T. Barrett, P.-P. Pastoret \& W. Taylor (eds.), Rinderpest and Peste des Petits Ruminants Virus. Plagues of large and small ruminants, pp. 144-162, Academic Press, London.

Leroy, E.M., Gonzalez, J.-P. \& Baize, S., 2011, 'Ebola and Marburg haemorrhagic fever viruses: Major scientific advances, but a relatively minor public health threat for Africa', Clinical Microbiology and Infection 17(7), 964-976. http://dx.doi. org/10.1111/j.1469-0691.2011.03535.x

Levi, T., Kilpatrick, A.M., Mangel, M. \& Wilmers, C.C., 2012, 'Deer, predators, and the emergence of Lyme disease', Proceedings of the National Academy of Sciences 109(27), 10942-10947. http://dx.doi.org/10.1073/pnas.1204536109

Mackenzie, J.S. \& Jeggo, M., 2013, 'Reservoirs and vectors of emerging viruses', Current Opinion in Virology 3(2), 170-179. http://dx.doi.org/10.1016/j. coviro.2013.02.002

Nath, B. G. \& Chakraborty, A., 2012, 'Tuberculosis in non-human primates of Assam: Use of PrimaTB STAT-PAK Assay for detection of tuberculosis', Journal of Threatened Taxa 4(4), 2541-2544.

Obanda, V., Poghon, J., Yongo, M., Mulei, I., Ngotho, M., Waititu K. et al., 2013, 'First reported case of fatal tuberculosis in a wild African elephant with past human-
wildlife contact', Epidemiology and Infection $141(7), 1476-1480$. http://dx.doi. wildlife contact', Epidemiology and
org/10.1017/S0950268813000022 
Pulliam, J.R.C., Epstein, J.H., Dushoff, J., Rahman, S.A, Bunning, M., Jamaluddin, A.A. et al., 2012, 'Agricultural intensification, priming for persistence and the Society 9(66), 89-101. http://dx.doi.org/10.1098/rsif.2011.0223

Randall, D.A., Williams, S.D., Kuzmin, I.V, Rupprecht, C.E., Tallents, L.A., Tefera, Z. et al. 2004, 'Rabies in Ethiopian wolves', Emerging Infectious Diseases 10(12), 10-13.

Randolph, S.E. \& Dobson, A.D., 2012, 'Pangloss revisited: A critique of the dilution effect and the biodiversity-buffers-disease paradigm', Parasitology 139(7), 847863. http://dx.doi.org/10.1017/S0031182012000200

Roche, B. \& Guégan, J.-F., 2011, 'Ecosystem dynamics, biological diversity and emerging infectious diseases', Comptes Rendus Biologies 334(5-6), 385-392. http://dx.doi.org/10.1016/j.crvi.2011.02.008

Sang, R. 2011, 'Crimean-Congo hemorrhagic fever virus in hyalommid ticks, northeastern Kenya', Emerging Infectious Diseases 17(8), 1502-1505. http:// dx.doi.org/10.3201/eid1708.102064
Sharp, P.M. \& Hahn, B.H., 2011, 'Origins of HIV and the AIDS pandemic', Cold Spring Harbor Perspectives in Medicine 1(1), a006841. http://dx.doi.org/10.1101/ cshperspect.a006841

Tang, X., Li, G., Vasilakis, N., Zhang, Y., Shi, Z., Zhong, Y. et al., 2009, 'Differential stepwise evolution of SARS coronavirus functional proteins in different host species', BMC Evolutionary Biology 9,52. http://dx.doi.org/10.1186/1471-2148speci

Wallace, R.G. \& Kock, R.A., 2012, 'Whose food footprint? Capitalism, agriculture and the environment', Human Geography 5(1), 63-83.

Wolfe, N.D., Dunavan, C.P. \& Diamond, J., 2007, 'Origins of major human infectious diseases', Nature.

Woodford, M.H., Butynski, T.M. \& Karesh, W.B.,2002, 'Habituating the great apes: The disease risks', Oryx 36, 153-160. http://dx.doi.org/10.1017/ S0030605302000224 